\title{
Upaya Mitigasi Dampak Covid-19 Melalui Kegiatan Pemberdayaan Masyarakat di Desa Banyuasin Kabupaten Bangka
}

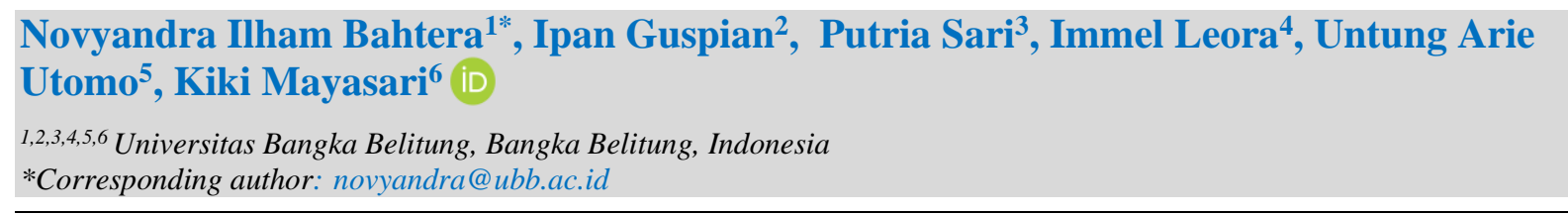

\begin{abstract}
Abstrak
Pandemi Covid-19 telah melanda seluruh dunia pada beberapa bulan terakhir. Hal ini memberikan dampak negatif pada sektor ekonomi dan sosial bagi masyarakat. Walau bagaimanapun, kondisi ini tidak boleh dibiarkan terus berlarut-larut. Perlu ada kegiatan kemasayarakatan agar masalah yang ada dapat diselesaikan. Tujuan kegiatan pengabdian kepada masyarakat di Desa Banyuasin Kabupaten Bangka adalah untuk memberikan kontribusi dan turut berpartisipasi aktif dalam usaha memitigasi dampak dari wabah Covid-19. Kegiatan pemberdayaan masayarakat ini terdiri dari empat bidang yaitu: bidang masyarakat; bidang lingkungan; bidang pendidikan; dan bidang kesehatan. Sosialisasi, pendampingan, kegiatan penyuluhan dan demonstrasi merupakan metode yang dilakukan dengan tetap mengikuti protokol pencegahan Covid-19. Kegiatan ini mendapatkan hasil bahwa masayarakat memberikan umpan balik yang positif dan memiliki kemauan agar kegiatan ini ada keberlanjutannya. Masyarakat mendapatkan manfaat yang dapat dirasakan dari berbagai bidang pada program yang ditawarkan. Kegiatan ini dapat sangat berguna bagi masyarakat Desa Banyuasin menjadi desa wisata berbasis pertanian.
\end{abstract}

Kata Kunci: Pulau Bangka, Desa Agrowisata, Pelatihan, Pemberdayaan Masyarakat, Peningkatan Pengetahuan

\section{Abstract}

Covid-19 becomes a pandemic that affects all countries all over the world. It creates a negative impact in the economic and social sector. However, it should not occur continuously. It requires a social activity to solve the issue. The aim of the community service program in Banyuasin is to contribute and be actively participated in mitigating the negative effect of the Covid-19. The program was broken into four sectors: society, environment, education and health. Socialisation, assitanship, extension, and demonstration were the methods of the program by following the Covid-19 health protocols. The program found that people in the village gave a positive feedback and expected that its sustainability. The beneficieries received advantages by participating into the offered program. The program was crucial to support the village becoming the agroturism village.

Keywords: Agrotourism Village, Bangka Island, Community Service, Capacity Building, Training

\section{INTRODUCTION}

Tahun 2020 menjadi tahun terberat bagi seluruh negara di dunia, termasuk indonesia. Hal ini dikarenakan adanya pandemi virus covid-19 yang disebabkan oleh virus sars-cov-2 (Fruehwirth et al., 2021; Liu, 2020). Pandemi ini bermula dari terinfeksi individu pertama di wuhan salah satu kota di republik rakyat tiongkok dan kemudian menyebar ke seluruh dunia (Li et al., 2020). Kasus terinfeksi covid-19 pertama di indonesia dikonfimasi oleh pemerintah indonesia pada tanggal 2 maret 2020, meskipun muncul beberapa spekulasi bahwa covid-19 telah masuk ke indonesia beberapa waktu sebelumnya (Yunus \& Rezki, 2020). Per 14 mei 2020 lalu, kasus positif covid-19 di indonesia sudah mencapai angka 16.006 jiwa dengan angka kesembuhan sebesar 3.518 jiwa dan angka kematian sebesar 1.043 jiwa (Handarini \& Wulandari, 2020). Semakin meningkatnya angka positif covid-19 di indonesia, pemerintah

$\begin{array}{ll}\text { History: } & \\ \text { Received } & \text { : April 24, } 2021 \\ \text { Revised } & \text { : April 26, } 2021 \\ \text { Accepted } & \text { : May 02, } 2021 \\ \text { Published } & \text { : May 25, } 2021\end{array}$


indonesia menerapkan beberapa langkah untuk memutuskan rantai penyebaran covid-19 seperti menganjurkan warganya untuk tetap berada di rumah hingga pemberlakukan aturan pembatasan sosial berskala besar (PSBB) (Pratiwi, 2021).

Pemberlakuan aturan PSBB akibat pandemi Covid-19 ini jelas memberikan dampak bagi berbagai sektor kehidupan masyarakat, diantaranya sektor pertanian, sektor pariwisata, sektor pendidikan, sektor sosial-ekonomi, dan sektor-sektor lainnya (Hanoatubun, 2020; Sari, 2020). Dampak yang paling besar terlihat dari sektor pendidikan dan sektor sosial-ekonomi masyarakat di Indonesia. Dari sektor pendidikan sendiri, kegiatan pembelajaran yang semula tatap muka kini berganti menjadi kegiatan belajar secara daring (Dewi, 2020; Mansyur, 2020). Sedangkan dari sektor sosial-ekonomi mulai adanya kemunduran dalam kinerja masyarakat dalam sektor ekonomi yang pada akhirnya berujung pada jatuhnya perekonomian pada skala nasional (Thaha, 2020; Yamali \& Putri, 2020).

Berdasarkan studi yang dilakukan oleh beberapa ahli bidang sosial yang memprediksi tingkat kemiskinan rata-rata di Indonesia akan meningkat di akhir tahun 2020 sehingga peningkatan tersebut akan menyebabkan sekitar 8 juta penduduk Indonesia megalami kemiskinan baru akibat pandemi Covid-19 ini (Rizal \& Mukaromah, 2021). Sehingga, diprediksi akhir tahun 2020 ini tingkat kemiskinan rata-rata Indonesia akan mencapai angka sebesar 9,7\% (Muhyiddin, 2020). Prediksi tingkat kemiskinan ini juga dilihat berdasarkan pertumbuhan ekonomi. Jika pertumbuhan ekonomi menurun $1 \%$, maka setidaknya akan menambah sekitar 1,4\% persentase kemiskinan. Tidak hanya itu, keadaan di lapangan juga akan berdampak sekitar 2,8 juta hingga 5,2 juta penduduk akan kehilangan pekerjaan saat pandemi ini menyebar. Kehilangan pekerjaan ini disebabkan adanya sistem pemutusan hubungan kerja (PHK) di beberapa perusahaan atau pabrik industri untuk menekan biaya produksi yang mengakibatkan meningkatnya pengangguran di Indonesia.

Dampak dari adanya pandemi covid-19 juga dirasakan oleh masyarakat di desa Banyuasin, Kecamatan Riau Silip, Kabupaten Bangka, Provinsi Kepualuan Bangka Belitung. Hal ini dikarenakan terdapat berbagai macam mata pencaharian yang dilakukan oleh masyarakat desa Banyuasin seperti karyawan (PNS, TNI/Polri, Swasta dan BUMN), wiraswasta atau pedagang, petani, buruh tani, nelayan, peternak, jasa, pengrajin, pekerja seni, pensiunan, dan bidang-bidang lainnya. Adanya pandemi covid-19 ini memberikan dampak yang besar terhadap perekonomian masyarakat, seperti pada masyarakat yang beprofesi menjadi pedagang tidak diperbolehkan untuk berdagang karna diberlakukannya kebijakn PSBB, serta masyarakat yang bekerja sebagai pekerja seni sudah tidak dapat memasarkan karya seninya karna kurangnya kunjungan wisatawan ke daerah tersebut. Adanya perubahan pada tatanan kehidupan ini mengakibatkan masyarakat harus siap dengan berbagai perubahan yang ada serta mulai berpikir kreatif untuk dapat terus menjalankan kehidupan di masa pandemi seperti saat ini (Prasetya et al., 2021). Sehingga diharapkan dapat menggerakkan kembali laju perekonomian nasional yang mengalami kemunduran beberapa waktu terakhir. Hal serupa pula dilakukan oleh pemerintah desa beserta masyarakat Desa Banyuasin. Disaat yang bersamaan, Desa Banyuasin saat ini sedang dalam proses mewujudkan visi dan misi menjadikan desa wisata pertanian yang mandiri dan sejahtera untuk meningkatkan perekonomian desa.

Peningkatan kreatifitas serta produktifitas masyarakat di masa pandemi covid seperti saat ini dapat dilakukan melalui proses pelatihan serta pemberdayaan masyarakat (Efendi et al., 2020; Tarigan, 2020). Program pelatihan serta pemberdayaan masyarakat dilakukan melalui kegiatan Kuliah Kerja Nyata XV Universitas Bangka Belitung (UBB), peserta mahasiswa kuliah kerja nyata dituntut untuk dapat mengamalkan ilmu pengetahuan dan teknologi serta dapat menjadi fasilitator, dinamisator maupun motivator dalam upaya mendukung pembangunan Desa Banyuasin sebagai desa wisata pertanian. Upaya pendukung 
yang dapat dilakukan oleh peserta Kuliah Kerja Nyata XV UBB Desa Banyuasin terbagi atas tiga program kerja utama, yaitu: 1) bidang masyarakat melalui Digital Marketing dengan memberikan pendampingan bagi UMKM Desa Banyuasin; 2) bidang pendidikan melalui English Day dengan memberikan bimbingan belajar bagi pelajar sekolah dasar dan menengah serta perangkat Desa Banyuasin; dan 3) bidang lingkungan melalui pekarangan biru dengan $\mathrm{Yu}$ Mina dan pembuatan tempat sampah untuk lingkungan persawahan wisata pertanian. Terdapat satu program kerja tambahan yaitu bidang kesehatan melalui pencegahan dan bantuan sosial Covid-19 dengan menyediakan alat cuci tangan bagi masyarakat Desa Banyuasin. Tujuan dilaksanakannya program ini adalah untuk memberikan kontribusi dan turut berpartisipasi aktif dalam usaha memitigasi dampak dari wabah Covid-19. Programprogram tersebut diharapkan dapat membantu Desa Banyuasin dalam menjaga ketahanan pangan masyarakat, mempersiapkan diri sebagai desa wisata pertanian, serta memperbaiki perekonomian serta sistem tatanan kehidupan masyarakat.

\section{MATERIALS AND METHODS}

Kegiatan pengabdian kepada masyarakat ini dilaksanakan di Desa Banyuasin, Kecamatan Riau Silip, Kabupaten Bangka, Provinsi Kepulauan Bangka Belitung mulai dari tanggal 15 Juli sampai dengan 19 Agustus 2020 atau sekitar 36 Hari. Kegiatan pengabdian ini telah didukung oleh Universitas Bangka Belitung, pemerintah desa, kelembagaan, dan seluruh masyarakat Desa Banyuasin. Kegiatan pengabdian kepada masyarakat di desa Banyuasin diikuti oleh seluruh masyarakat desa Banyuasin serta 15 orang mahasiswa yang terdiri dari dua fakultas dan empat program studi yang ada di Universitas Bangka Belitung. Komposisi mahasiswa yang tergabung dalam Tim Pengabdian kepada Masyarakat dapat dilihat pada table 1

Tabel 1. Data Komposisi Tim Pelaksana Pengabdian kepada Masyarakat Desa Banyuasin Tahun 2020

\begin{tabular}{lc}
\hline \multicolumn{1}{c}{ Program Studi/Fakultas } & Jumlah (Orang) \\
\hline Agribisnis/Fakultas Pertanian, Perikanan, dan Biologi & 8 Orang \\
Biologi/Fakultas Pertanian, Perikanan, dan Biologi & 1 Orang \\
Akuakultur/Fakultas Pertanian, Perikanan, dan Biologi & 3 Orang \\
Sastra Inggris/Fakultas Ilmu Sosial dan Ilmu Politik & 3 Orang \\
\hline
\end{tabular}

Pelaksanaan kegiatan program pengabdian kepada masyarakat diawali dengan kegiatan penyuluhan serta sosialisasi program kepada masyarakat, yang kemudia dilanjutkan ke tahap pelaksanaan program. Terdapat 4 program yang dijalankan dalam program pengabdian masyarakat di Desa Banyuasin, program tersebut terdiri dari kegiatan workshop digital marketing dan kunjungan pendampingan UMKM, pekarangan biru dengan yu mina, bimbingan belajar bahasa inggris bagi pelajar dan perangkat Desa Banyuasin, pencegahan Covid-19. Pertama, kegiatan pendampingan UMKM diawali dengan pencarian informasi UMKM yang terdapat di Desa Banyuasin. Kemudian, dilanjutkan dengan mendatangi masyarakat dari rumah ke rumah untuk mengidentifikasi pelaku UMKM. Kemudian, pelaksana pengabdian melakukan wawancara langsung yang didampingi oleh salah satu perangkat desa. Hasil wawancara tersebut dijadikan tabel identifikasi permasalahan UMKM untuk ditindaklanjuti oleh pihak Desa Banyuasin.

Kedua, yakni kegiatan bimbingan belajar English Day yang diikuti oleh perangkat desa beserta pelajar Desa Banyuasin. Kegiatan ini dilakukan sebanyak dua kali pertemuan dalam satu pekan dimana satu pertemuan untuk perangkat desa dan satu pertemuan untuk 
pelajar. Setiap sesi dilaksanakan dalam kurun waktu belajar selama 45 menit dan latihan atau diskusi selama 15 menit. Sehingga, total per sesi menjadi 60 menit. Setiap satu sesi menyediakan materi yang dibutuhkan peserta. Sesi pertama mengenaiVocabulary, kedua tentang Grammar, keempat berupa Spelling, dan yang terakhir adalah Speaking. Ketiga, yakni kegiatan pembuatan pekarangan biru yang dilaksanakn mulai dari dari proses persiapan lahan dan persiapan alat dan bahan, lalu percetakan kolam dan pengisian serta pengendapan air. Setelah kurang lebih tiga sampai empat hari, ikan siap dimasukkan ke dalam kolam. Kemudian, dilanjutkan dengan persiapan media tanam sayuran, dan menyiapkan rak atau tempat menyimpan tanaman yang telah ditanam di dalam polibag. Setelah menyiapkan media tanam dan rak penyimpanan, medai tanam dimasukkan ke dalam polibag dengan langsung memasukkan benih sayuran ke dalamnya. Setelah diisikan dengan benih tersebut polibag yang sudah berisikan benih disusun di rak penyimpanan yang telah dibuatkan.

Keempat, yakni program tambahan berupa pembuatan brosur New Normal dan penyediaan alat cuci tangan untuk tempat umum merupakan kegiatan tambahan di bidang kesehatan. Proses pembuatan brosur New Normal menggunakan bantuan aplikasi editor yang mendukung dan selanjutnya dicetak untuk kemudian disebarluaskan kepada masyarakat Desa Banyuasin. Proses pembuatan alat cuci tangan menggunakan barang-barang bekas seperti ember yang selanjutnya diberikan hiasan dan tulisan karya KKN XV UBB Desa Banyuasin 2020. Alat dan bahan yang dibutuhkan selama pelaksanaan kegiatan disesuaikan dengan kebutuhan setiap program. Rincian alat dan bahan dapat dilihat pada table 2 .

Tabel 2. Kebutuhan Program Kerja Pengabdian kepada Masyarakat Desa Banyuasin Tahun 2020

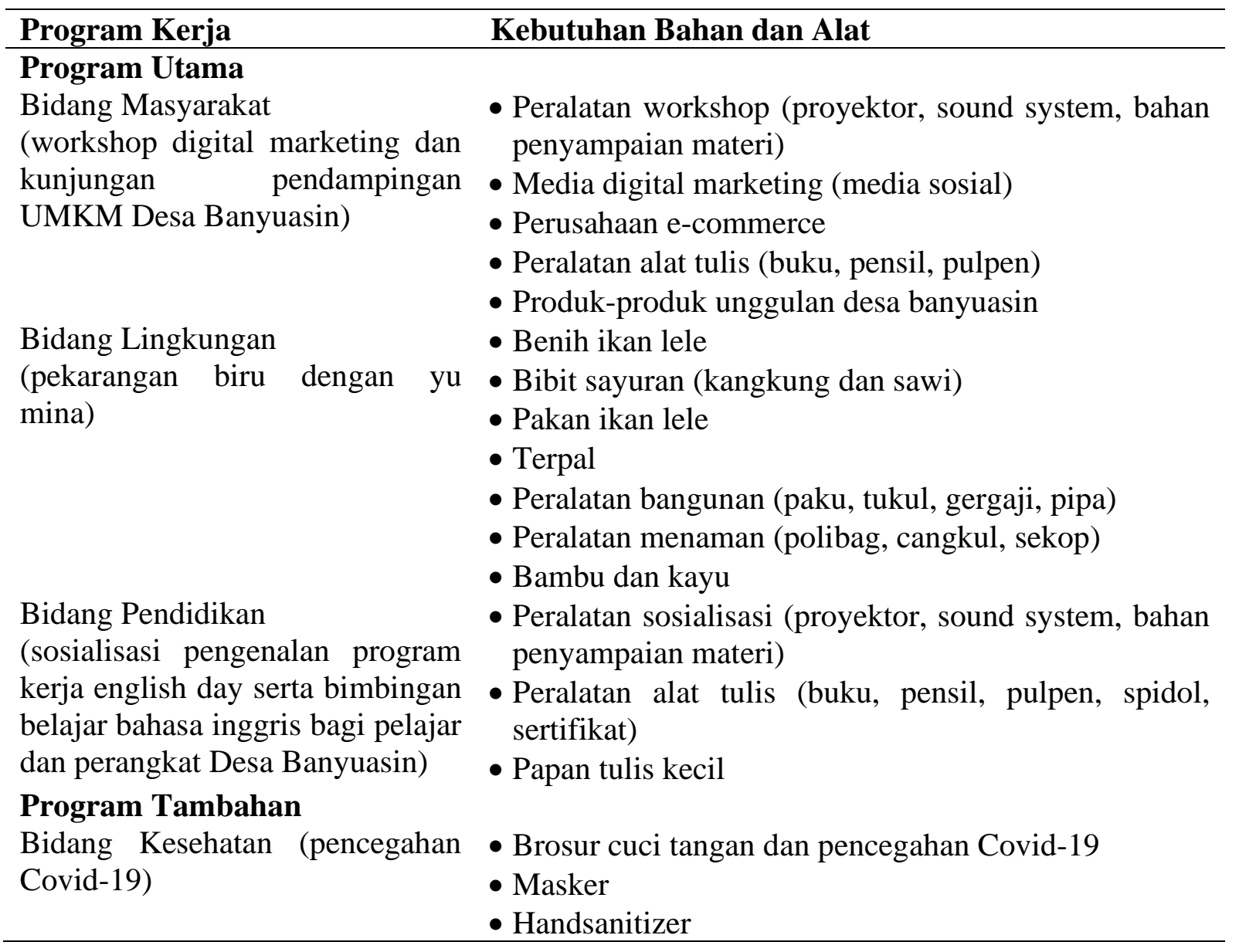




\begin{tabular}{ll}
\hline Program Kerja & Kebutuhan Bahan dan Alat \\
\hline & - Handsoap \\
& - Penyediaan alat cuci tangan \\
& $\bullet$ Peralatan lainnya (cat warna, bor, kuas, lem) \\
\hline
\end{tabular}

\section{RESULTS AND DISCUSSION}

Pengabdian kepada masyarakat adalah usaha untuk menyebarluaskan ilmu pengetahuan, teknologi, dan seni kepada masyarakat (Alfianto, 2012; Riduwan, 2016). Kegiatan tersebut harus mampu memberikan suatu nilai tambah bagi masyarakat, baik dalam kegiatan ekonomi, kebijakan, dan perubahan perilaku sosial. Kegiatan yang dilakukan oleh tim pelaksana pengabdian kepada masyarakat ini telah mampu memberi perubahan dalam beberapa bidang bagi individu masyarakat maupun perangkat Desa Banyuasin baik dalam jangka pendek maupun jangka panjang. Seperti yang telah dijelaskan sebelumya bahwa kegiatan pengabdian masyarakat di Desa Banyuasin dilaksankan dalam 4 program kegiatan yang terdiri dari kegiatan workshop digital marketing dan kunjungan pendampingan UMKM, pekarangan biru dengan yu mina, bimbingan belajar bahasa inggris bagi pelajar dan perangkat Desa Banyuasin, dan pencegahan Covid-19. Adapun hasil dari setiap program kegiatan adalah sebagai berikut: Pertama, pada kegiatan workoshop digital marketing diambil tema "Sosialisasi dan Pelatihan Pemasaran Digital untuk Peningkatan Kapasitas dan Pendapatan pada Industri Rumahan Desa Banyuasin, Kabupaten Bangka". Tujuan dari kegiatan ini adalah memberikan pemahaman mengenai pemasaran digital produk-produk unggulan dan peningkatan peluang usaha bagi pelaku UMKM Desa Banyuasin selama masa pandemi Covid-19 untuk meningkatkan pendapatan masyarakat dan desa. Kegiatan ini penting karena pemasaran melalui teknologi digital sangat dapat membantu kegiatan bisnis. Kegiatan Workshop Digital Marketing ini menghadirkan narasumber yang sudah memiliki kemampuan dalam bidang pemasaran baik daring maupun luring yaitu Ferdinan Hendrata yang menjabat sebagai CEO boleh.id, salah satu perusahaan e-commerce di Provinsi Kepulauan Bangka Belitung. Peserta yang turut hadir dalam kegiatan ini sebanyak 35 orang yang terdiri dari perangkat desa, pelaku UMKM, dan masyarakat Desa Banyuasin.

Hasil dari pelaksanaan kegiatan workshop menunjukkan bahwa masyarakat sangat tertarik dengan penyampaian materi oleh narasumber mengenai cara menggunakan media digital untuk kegiatan pemasaran diantaranya media sosial (seperti: Instagram, Facebook), SMS, Email Marketing, dan Market Place (seperti: Tokopedia, Shopee). Selain itu, narasumber juga memberikan tips dalam memasarkan produk di media sosial. Materi yang disampaikan oleh narasumber ini diharapkan dapat diterapkan langsung oleh para pelaku UMKM Desa Banyuasin dalam memahami cara penggunaan media digital untuk pemasaran. Ini penting karena saat ini konsumen cenderung menggeser cara pembelian nya dari konvensional ke penggunaan digitalisasi (Verhoef \& Bijmolt, 2019; Rangaswamy et al., 2020). Pelaksanaan kegiatan workshop digital marketing sangatlah dibutuhkan masyarakat kususnya di masa pandemi saat ini. Hal ini dikarenakan dengan adanya pandemi dan kebijikan PSBB masyarakat tidak dapat bekerja dengan maksimal dan lebih banyak dianjurkan untuk tetap dirumah. Sehingga pemanfaatan teknologi untuk mengembangkan usaha sangatlah bermanfaat untuk masyarakat. Seperti yang telah diketahui bersama bahwa di era globalisasi ini perkembangan teknologi menjadi semakin pesat, dimana seluruh aktifitas kehidupan manusia dapat dipermudah melalui penggunaan teknologi, dan dengan adanya pandemi covid-19 ini juga menuntut masyarakat untuk melek teknologi dan memanfaatkan teknologi dengan baik dan cerdas untuk meningkatkan taraf hidup.

Selanjutnya pada program kerja bidang masyarakat terdapat program kerja pendampingan UMKM, yang dilakukan untuk mengetahui kendala dan permasalahan yang 
dihadapi oleh UMKM dalam memasarkan serta membantu para pelaku UMKM dalam mengatasi permasalahan dan pengemasan produk yang baik. Sebanyak empat UMKM yang dikunjungi oleh tim bidang masyarakat dengan berbagai jenis produk yang terdiri dari produk beras aruk, gula aren, aneka kemplang, dan keripik ubi. Berdasarkan hasil identifikasi permasalahan di beberapa UMKM Desa Banyuasin, diperoleh enam permasalahan utama yang dihadapi yaitu: 1) kemasan yang digunakan masih berupa plastik; 2) cuaca/iklim; 3) keterbatasan jumlah bahan baku utama; 4) belum adanya label dan PIRT (Perizinan Industri Rumah Tangga) pada kemasan; 5) peralatan untuk proses produksi tidak memadai; dan 6) keterbatasan Modal. Seringkali UMKM menghadapi kendala pada non finansial dan finansial yang disebabkan oleh ketidakpahaman para pelaku UMKM mengenai cara peningkatkan kualitas dan perizinan produknya (Kurniawati et al., 2012; Suci, 2013). Oleh karena itu, dilakukan kegiatan pendampingan UMKM agar dapat mengembangkan peluang usaha produk-produk unggulan khususnya di Desa Banyuasin.

Pelaksanaan pendampingan UMKM di Desa Banyuasin hanya dapat terlaksana sampai pada tahap identifikasi, hal ini dikarenakan adanya keterbatasan waktu pelaksanaan program, sehingga untuk program selanjutnya akan ditangani oleh pihak pemerintah Desa Banyuasin. Dengan adanya kegiatan pendampingan UMKM ini, masyarakat mengharapkan kegiatan ini menjadi kegiatan berkelanjutan. Hal ini dikarenakan kegiatan ini dapat membantu para pelaku UMKM untuk mengatasi berbagai permasalahan yang ada, terutama dalam hal pengemasan, perizinan usaha, dan penggunaan media sosial untuk pemasaran produk-produk unggulan Desa Banyuasin. Selain itu, dari kegiatan ini telah dijadikan perangkat desa sebagai program desa dalam membantu para pelaku UMKM menghasilkan produk-produk unggulan sebagai upaya pendukung Desa Banyuasin sebagai desa wisata pertanian seperti cinderamata bagi para wisatawan.

Program kerja yang Kedua adalah program kerja pada bidang lingkungan yakni Pekarangan Biru dengan Yu Mina. Yu mina merupakan kolam yang tidak hanya dapat menghasilkan ikan, tetapi juga dapat menghasilkan sayuran tertentu dengan memanfaatkan tempat budidaya ikan air tawar (Oktavianna et al., 2019). Pekarangan Biru dengan menggunakan Metode Yu Mina dapat memberikan dampak positif dalam hal pemanfaatan lahan kususnya bagi masyarakat yang memiliki lahan atau pekarangan sempit (Masitoh et al., 2020; Nugroho et al., 2020). Selain tidak membutuhkan lahan yang luas program pekarangan biru dengan menggunakan metode Yu Mina tidak membutuhkan peralatan kusus, dimana peralatan yang digunakan dalam pembuatan pekarangan biru ini sangat mudah dijumpai di berbagai toko peralatan bangunan sekitar tempat tinggal masyarakat.

Program Pekarangan Biru dengan Yu Mina dilakukan dengan membudidayakan 2000 benih lele dan jenis sayuran yang di budidaya yaitu kangkung. Teknologi budidaya ikan dengan Yu Mina ini memiliki keunggulan dan manfaat bagi masyarakat Desa Banyuasin, yakni meningkatkan produktivitas lahan, meningkatkan pendapatan, ramah lingkungan (ekonomi biru), mengurangi biaya produksi budidaya tanaman sayuran, dan menjaga ketahanan pangan (Cahya et al., 2021). Selain itu, penggunaan sistem sirkulasi pada kolam ikan dapat memacu ikan lele tumbuh lebih cepat. Hal ini disebabkan karena kondisi oksigen pada kolam ikan lele melimpah. Pada kondisi ini, ikan akan mendapatkan pasokan oksigen lebih di dalam darah dan memacu metabolisme tubuh ikan dengan baik. Jika sirkulasi teknik Yu Mina ini dapat berjalan baik, benih ikan lele dapat dipanen sebelum tiga bulan. 


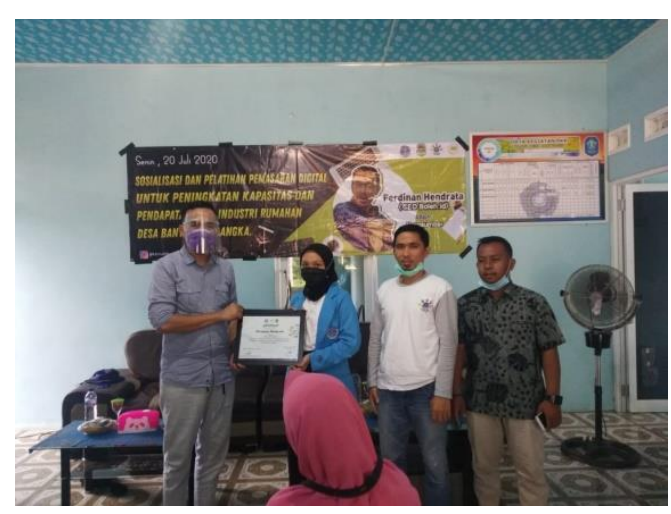

Gambar 1. Penyerahan Sertifikat Narasumber Workshop Digital Marketing

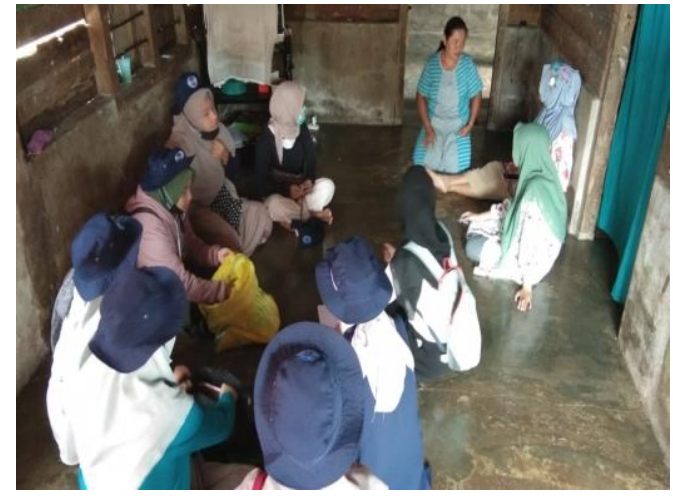

Gambar 2. Kunjungan dan Pendampingan Salah Satu UMKM Desa Banyuasin (Produk: Beras Aruk)

Selain itu, air kolam ikan dalam metode Yu Mina ini berguna sebagai pupuk organik cair bagi tanaman sayuran yang dibudidayakan disamping kolam ikan lele. Hal ini dikarenakan dalam air kolam ikan tersebut terdapat sisa pakan dan kotoran ikan lele yang bermanfaat baik bagi tanaman. Hasil tanaman yang disiram dengan air kolam ikan akan tumbuh subur dengan baik dan akan mengurangi biaya pembelian pupuk untuk budidaya sayuran di pekarangan rumah. Berdasarkan hasil pembudidayaan ikan lele dan sayuran pekarangan biru yang dibuat oleh tim pelaksana, diperoleh bahwa sayur kangkung yang ditanam telah dapat dipanen selama 28 Hari dari mulai proses penyemaian awal sampai panen dengan berat tiga kilogram dan ukuran panjang sayuran $25 \mathrm{~cm}$. Sementara itu, hasil ikan lele belum dapat dilakukan pemanenan. Hal ini dikarenakan masih adanya perbedaan ukuran pada ikan lele yang kemungkinan disebabkan karena kurangnya melakukan kegiatan kontrol ikan lele oleh pihak desa yang melanjutkan program ini. Selain itu, kemungkinan disebabkan karena kurangnya pemahaman pihak desa mengenai pembudidayaan ikan lele ini. Perkiraan ikan lele yang dibudidayakan ini akan dapat dipanen pada bulan Oktober 2020.

Program ketiga yakni program yang menaungi bidang pendidikan kususnya pada pendidikan bahasa Inggris yang dinamakan dengan program kerja English day. Tujuan dari pelaksanaan program ini adalah untuk meningkatkan kemampuan berbahasa Inggris anakanak serta perangkat desa di Desa Banyuasin. Pelaksanaan kegiatan English Day diawali dengan kegiatan sosialisasi yang bertujuan untuk mengenalkan program kerja English Day kepada pelajar dan perangkat desa mengenai sistematis pembelajaran Bahasa Inggris yang dilaksanakan setiap pekan selama satu bulan. Peserta yang turut hadir dalam kegiatan ini sebanyak 35 orang yang terdiri dari perangkat desa dan pelajar di Desa Banyuasin. Hasil dari kegiatan sosialisasi menunjukkan bahwa para peserta yang hadir sangat tertarik dengan adanya program ini dan sangat mendukung dengan program desa yang akan menjadikan Desa Banyuasin sebagai desa wisata. Hal ini dikarenakan masih minimnya sumber daya manusia di bidang pendidikan untuk mampu meningkatkan kualitas pengetahuan yang ada di Desa Banyuasin. Selain itu, Desa Banyuasin perlu adanya SDM yang mampu berbahasa internasional untuk mendukung sebagai desa wisata pertanian. Meskipun terkadang materi yang disampaikan belum tentu menggambarkan kondisi nyata di lapangan (Sang Hyeon et al., 2017). Oleh karena itu, Kepala Desa Banyuasin beserta perangkat desa lainnya mengharapkan agar kegiatan ini dapat menjadi program berkelanjutan di bidang pendidikan untuk Desa Banyuasin. 


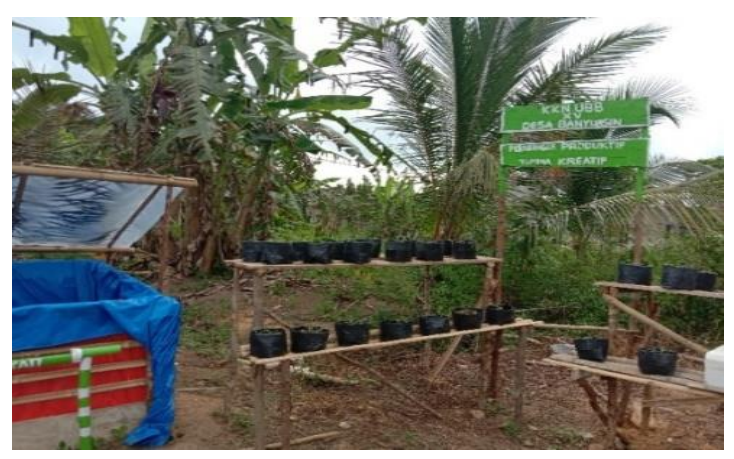

Gambar 3. Pekarangan Biru Metode Yu Mina

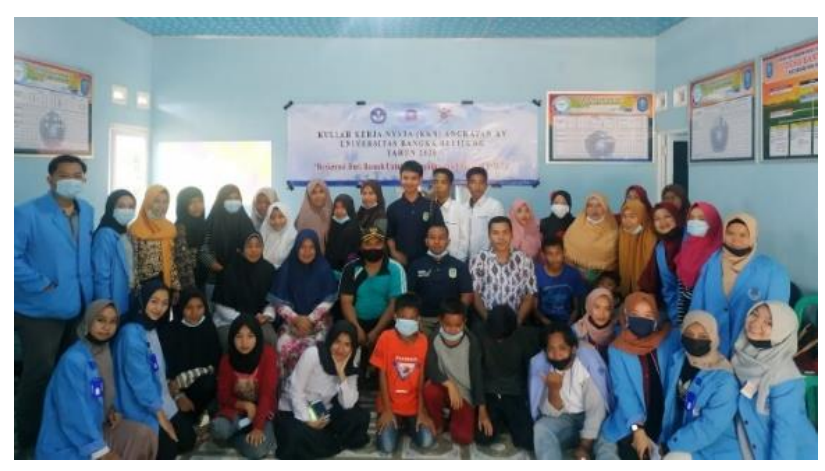

Gambar 4. Foto Bersama Tim Pelaksana dan Peserta Sosialisasi Pengenalan English Day

Setelah pelaksanaan sosialisasi dan program dapat diterima dengan baik oleh masyarakat, kegiatan dilanjutkan dengan tahap pelaksanaan program. Kegiatan bimbingan belajar ini merupakan kegiatan utama dalam bidang pendidikan. Peserta yang ikut serta dalam kegiatan ini sebanyak 14 orang yang terdiri dari Pelajar dan Perangkat Desa Banyuasin. Setiap kali pertemuan, tim pengajar menetapkan target agar pemahaman peserta dalam berbahasa inggris dapat tercapai. Selain itu, dalam upaya meningkatkan semangat belajar peserta, tim pengajar memberikan penghargaan berupa bingkisan kecil di setiap pertemuan, sertifikat, dan buku saku materi bahasa inggris. Berdasarkan hasil data olahan Tim Pengajar English Day mengenai pemahaman dan materi penyampaian dari pelaksanaan kegiatan bimbingan belajar English Day ini, kegiatan bimbingan belajar English Day yang dilaksanakan oleh tim pelaksana pengabdian kepada masyarakat Desa Banyuasin sangat membantu dalam memahami bahasa inggris dan materi yang disampaikan oleh tim pengajar mudah dipahami oleh para peserta kegiatan yang terdiri dari Pelajar dan Perangkat Desa. Hal ini dikarenakan tim pengajar merupakan mahasiswi Program Studi Sastra Inggris Universitas Bangka Belitung yang mampu mengimplementasikan pembelajaran perkuliahan dalam kegiatan bimbingan belajar ini dengan baik.

Terdapat sebanyak $71,43 \%$ peserta menyatakan sudah mengetahui beberapa kosakata dalam bahasa inggris sebelum mengikuti kegiatan bimbingan belajar English Day ini yang diperoleh dari pembelajaran di sekolah. Sementara itu, 28,57\% dari peserta menyatakan belum mengetahui kosa kata dalam bahasa inggris sebelum mengikuti kegiatan ini Bimbingan Belajar English Day karena tidak terlalu mengerti mengenai kosa kata dalam bahasa inggris. Hasil ini menyatakan bahwa kegiatan bimbingan belajar ini berguna untuk lebih memperdalam pemahaman dan kemampuan bahasa inggris yang sudah diperoleh dari pembelajaran di sekolah. Berdasarkan hasil yang diperoleh dari kegiatan bimbingan belajar ini, sebesar 92,86\% memperoleh ilmu mengenai kosa kata bahasa inggris. Sedangkan, sisanya sebesar $7,14 \%$ menambah pengalaman dan bagi para perangkat desa untuk mengingat kembali pembelajaran bahasa inggris waktu masih duduk di bangku sekolah dulu. Hal ini mengindikasikan bahwa adanya kegiatan bimbingan belajar ini dapat meningkatkan ilmu pengetahuan peserta dalam berbahasa inggris. Kesan yang dirasakan oleh peserta kegiatan bimbingan belajar English Day ini sangat menyenangkan dan mudah memahami Bahasa Inggris karena tim pengajar mampu membawa suasana bimbingan belajar menjadi kondusif dan lancar. Pesan yang disampaikan yaitu ucapan terima kasih kepada tim pengajar dan seluruh panitia pelaksana bimbingan belajar ini yang bersedia membantu mereka dalam mempelajari bahasa inggris. Para peserta berharap agar kegiatan ini dapat menjadi kegiatan berkelanjutan khusus untuk bidang pendidikan di Desa Banyuasin.

Program keempat adalah program yang berkaitan dengan bidang kesehatan yakni Pembuatan dan Pembagian Brosur New Normal Covid-19 beserta Fasilitas Alat Cuci Tangan. 
Kegiatan Pencegahan Covid-19 ini merupakan program tambahan di bidang kesehatan. Pencegahan Covid-19 yang dilakukan oleh tim pelaksana pengabdian kepada masyarakat Desa Banyuasin adalah pembagian brosur New Normal dan penyediaan alat cuci tangan untuk tempat umum sekitar Desa Banyuasin. Tujuan dari kegiatan ini adalah untuk memberikan pemahaman kepada masyarakat Desa Banyuasin mengenai protokol kesehatan dalam tatanan New Normal yang harus dipatuhi dan memberikan salah satu objek penerapan kelaziman baru berupa penyediaan alat cuci tangan sebanyak tujuh unit untuk mencegah penyebaran Covid-19. Hal ini dilakukan karena masih kurangnya kesadaran masyarakat Desa Banyuasin dalam penerapan protokol kesehatan di tempat umum dan belum memahami mengenai tatanan kehidupan baru (New Normal).

Penyediaan fasilitas cuci tangan di beberapa titik desa ini telah sesuai dengan anjuran pemerintah yang mengharuskan masyarakat untuk rajin mencuci tangan dengan sabun dan slalu menggunakan masker saat berpergian. Hasil dari kegiatan ini yaitu adanya peningkatan pemahaman masyarakat Desa Banyuasin mengenai New Normal dan tindakan pencegahan selama masa pandemi Covid-19 ini. Selain itu, masyarakat Desa Banyuasin mulai membiasakan kebiasaan baru, seperti menggunakan masker saat berpergiaan dan mencuci tangan sebelum dan sesudah memasuki tempat umum di Desa Banyuasin. Oleh karena itu, fasilitas yang telah diberikan tersebut diharapkan dapat membantu meningkatkan kesadaran masyarakat dalam mencegah wabah virus Covid-19 menyebar di Desa Banyuasin.

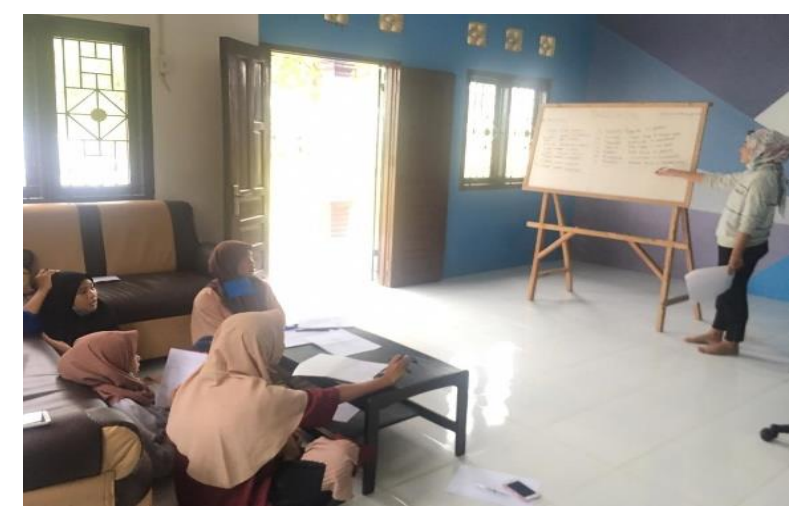

Gambar 5. Proses Bimbingan Belajar English Day bagi Pelajar dan Perangkat Desa Banyuasin

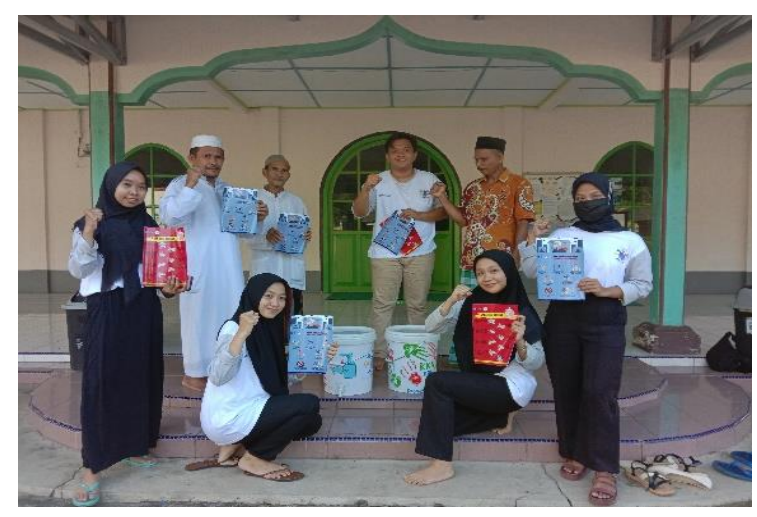

Gambar 6. Pembagian Brosur New Normal Covid-19 dan Alat Cuci Tangan kepada Pihak Pengelola Masjid Desa Banyuasin.

\section{CONCLUSION}

Program pengabdian kepada masyarakat dilakukan di Desa Banyuasin, Kecamatan Riau Silip, Kabupaten Bangka, Provinsi Kepulauan Bangka Belitung mulai dari tanggal 15 Juli sampai dengan 19 Agustus 2020 atau sekitar 36 Hari. Kegiatan pengabdian masyarakat ini diikuti oleh 15 orang mahasiswa dari Universitas Bangka Belitung dan seluruh masyarakat Desa Banyuasin. Dalam pelaksanaan kegiatan terdapat 4 program kerja yang dijalankan oleh mahasiswa peserta KKN, yang terdiri dari kegiatan workshop digital marketing dan kunjungan pendampingan UMKM, pekarangan biru dengan yu mina, bimbingan belajar bahasa inggris bagi pelajar dan perangkat Desa Banyuasin, pencegahan Covid-19.

Pelaksanaan kegiatan yang dilakukan oleh tim pelaksana pengabdian kepada masyarakat Desa Banyuasin Tahun 2020 telah memperlihatkan bahwa setiap program kerja dan kegiatan tim pengabdian kepada masyarakat Desa Banyuasin ini sangat mendukung dan sesuai dengan program Pemerintah Desa dalam upaya mewujudkan Desa Banyuasin sebagai desa wisata berbasis pertanian. Para pelaku UMKM sangat terbantu dengan adanya program 
Digital Marketing dalam mengembangkan peluang usaha dan memasarkan produk-produk unggulan khas Desa Banyuasin dengan menggunakan media sosial sebagai perantara proses pemasaran. Hal ini dapat berimplikasi pada potensi peningkatan pendapatan di sektor UMKM yang ada di Desa Banyuasin

Selanjutnya dari sisi pertanian telah terjadi peningkatan pengetahuan masyarakat Desa Banyuasin mengenai pemanfaatan lahan sempit di pekarangan rumah dengan adanya program Pekarangan Biru dengan metode Yu Mina yang memiliki keunggulan yakni meningkatkan produktivitas lahan, meningkatkan pendapatan, ramah lingkungan (ekonomi biru), mengurangi biaya produksi budidaya tanaman sayuran, dan menjaga ketahanan pangan masyarakat Desa Banyuasin. Sedangkan dari sisi kebahasaan, adanya peningkatan pengetahuan dan kemampuan masyarakat Desa Banyuasin dalam berbahasa asing melalui program English Day sebagai upaya mendukung Desa Banyuasin sebagai desa wisata pertanian berupa penambahan beberapa kosakata dan pengucapan bahasa inggris dengan baik dan benar. Hal ini tentu dapat mendukung semangat masyarakat menuju dewa agrowisata

Terakhir, adanya peningkatan kesadaran dan pemahaman masyarakat Desa Banyuasin mengenai protokol kesehatan dalam tatanan kehidupan baru (New Normal) yang harus dipatuhi selama pandemi Covid-19 melalui pesan dari brosur yang telah disebarkan. Hal ini didukung dengan tersedianya objek penerapan kebiasaan baru selama New Normal berupa alat cuci tangan di beberapa tempat umum sekitar Desa Banyuasin agar dapat menghindari atau mencegah virus Covid-19. Hal ini menunjukkan bahwa masyarakat Desa Banyuasin patuh terhadap peraturan daerah dan pusat sehingga sinergitas masyarakat terhadap program desa mampu terlaksana sesuai dengan aturan pusat.

Setiap program yang telah diberikan perlu dilakukan keberlanjutan agar kegiatan ini tidak berhenti sekedar dari program KKN saja. Program ini perlu digulirkan dengan melibatkan dinas terkait agar penyebaran ilmu pengetahuan dan teknologi yang telah dilaksanakan mampu menjadi bagian dari masyarakat. Ini diharapkan setiap elemen masyarakat yang ada di Desa Banyuasin mampu mandiri dalam mengembangkan dan menumbuhkan kegiatan pariwisata berbasis pertanian sehingga mampu meginspirasi desa lain di Kabupaten Bangka bahkan hingga di Provinsi Kepulauan Bangka Belitung.

\section{ACKNOWLEDGMENTS}

Kami ucapkan rasa terima kasih kepada lembaga penelitian dan pengabdian kepada masyarakat (LPPM) Universitas Bangka Belitung atas dukungan moril maupun materil pada proses aktifitas di lapangan. Program ini didanai dengan skema Kuliah Kerja Nyata XV UBB yang diberikan oleh Universitas Bangka Belitung dengan SK Rektor No. 8.16/UN50/AM/VI/2020.

\section{REFERENCES}

Alfianto, E. A. (2012). Kewirausahaan: Sebuah Kajian Pengabdian Kepada Masyarakat. Jurnal Heritage, 1(2), 33-42. https://jurnal.yudharta.ac.id/v2/index.php/HERITAGE/article/view/837/691.

Cahya, M. D., Yustiati, A., \& Andriani, Y. (2021). Sistem Budidaya Polikultur dan Integrated Multi Trophic Aquaculture (IMTA) di Indonesia: Sebuah Ulasan. Journal of Fisheries and Marine Science, 4(2), 72-85. https://journal.unhas.ac.id/index.php/torani/article/view/13668.

Dewi, W. A. F. (2020). Dampak Covid-19 Terhadap Implementasi Pembelajaran Daring Di Sekolah Dasar. Jurnal Ilmu Pendidikan, 2(1), 55-61. https://doi.org/https://doi.org/10.31004/edukatif.v2i1.89. 
Efendi, E., Rachmadan, S., Guntoro, D., Putri, D. S., Marzuki, A., Azhmi, A. Al, Khoirunisa, D. D., Sintia, I., Hikmah, N., \& Sari, Y. P. (2020). Meningkatkan perekonomian masyarakat di masa new normal melalui kegiatan ekonomi kreatif usaha dengan memanfaatkan media online. Jurnal Pembelajaran Pemberdayaan Masyarakat, 1(4), 259-264. http://www.riset.unisma.ac.id/index.php/JP2M /article/view/8776/7625.

Fruehwirth, J. C., Biswas, S., \& Perreira, K. M. (2021). The Covid-19 pandemic and mental health of first-year college students: Examining the effect of Covid-19 stressors using longitudinal data. PLOS ONE, 16(3), e0247999. https://doi.org/10.1371/journal.pone.0247999.

Handarini, O. I., \& Wulandari, S. S. (2020). Pembelajaran Daring Sebagai Upaya Study From Home (SFH) Selama Pandemi Covid 19. Jurnal Pendidikan Administrasi Perkantoran (JPAP), 8(3), 496-503.

Hanoatubun, S. (2020). Dampak Pandemi COVID-19 terhadap Perekonomian Indonesia. Jurnal of Education, Psychology, and Counseling, 5(2), 212. https://doi.org/10.22216/jbe.v5i2.5313.

Kurniawati, E. P., Nugroho, P. I., \& Arifin, C. (2012). Penerapan Akuntansi Pada Usaha Mikro Kecil Dan Menengah (UMKM). Jurnal Manajemen Dan Keuangan, 10(2). https://jurnal.darmajaya.ac.id /index.php/jmk/article/view/332/pdf.

Li, Q., Guan, X., Wu, P., Wang, X., Zhou, L., Tong, Y., Ren, R., Leung, K. S. M., Lau, E. H. Y., Wong, J. Y., Xing, X., Xiang, N., Wu, Y., Li, C., Chen, Q., Li, D., Liu, T., Zhao, J., Liu, M., ... Feng, Z. (2020). Early Transmission Dynamics in Wuhan, China, of Novel Coronavirus-Infected Pneumonia. New England Journal of Medicine, 382(13), 1199-1207. https://doi.org/10.1056/nejmoa2001316.

Liu, L. (2020). Sustainable COVID-19 Mitigation: Wuhan Lockdowns, Health Inequities, and Patient Evacuation. International Journal of Health Policy and Management, 9(10), 415 - 418. https://doi.org/10.34172/ijhpm.2020.63.

Mansyur, A. R. (2020). Dampak COVID-19 Terhadap Dinamika Pembelajaran Di Indonesia. Education and Learning Journal, 1(2), 113-123. https://doi.org/10.33096/eljour.v1i2.55.

Masitoh, N., Sudaryanti, dedeh sri, Munawan, andri helmi, \& Rahmawati, M. (2020). Optimalisasi Kawasan Rumah Pangan Lestari Dengan Budikdamber Untuk Meningkatkan Ketahanan Pangan Masyarakat Di Masa Pandemic Covid-19 Di Desa Sukamahi Kecamatan Sukaratu Kabupaten Tasikmalaya. Jurnal Pengabdian Kepada Masyarakat, $\quad$ 1(3), $111-122 . \quad$ http://www.openjournal. unpam.ac.id/index.php/kommas/article/view/8602/5547.

Muhyiddin. (2020). Covid-19, New Normal dan Perencanaan Pembangunan di Indonesia. Jurnal Perencanaan Pembangunan: The Indonesian Journal of Development Planning, $4(2)$, $240-252$. https://journal.bappenas.go.id/index.php/jpp/article/view/118/89.

Nugroho, R. A., Rahmadi, A., Saputra, F. A., Nabila, R., Suratmi, Wardana, D., Wibowo, A. I. D. N., \& Laila, N. M. A. (2020). Edukasi Covid-19 dan pemberdayaan masyarakat melalui program KKN KLB, desa Kelinjau Ulu, Muara Ancalong, Kutai Timur Kalimantan Timur. Seminar Nasional Hasil Pengabdian Kepada Masyarakat, 1-8. http://www.openjournal.unpam.ac.id/index.php/kommas/article/view /8602/5547.

Oktavianna, R., Pratama, A., \& Sulistiyani. (2019). Kontribusi Kolam Ikan "Yumina Bumina" Sebagai Upaya Peningkatan Pendapatan Keluarga Di Desa Jampang Bogor. Economy Deposit Journal, 1(2), 74-80. https://doi.org/https://doi.org/10.36090/edj.v1i2.572.

Prasetya, A., Nurdin, M. F., \& Gunawan, W. (2021). Perubahan Sosial Masyarakat dalam Perspektif Sosiologi Talcott Parsons di Era New Normal. Sosietas Jurnal Pendidikan 
Sosiologi,

11(1),

929-939. https://doi.org/https://doi.org/10.17509/sosietas.v11i1.36088.

Pratiwi, D. K. (2021). Inovasi Kebijakan Pemerintah Daerah dalam Penanganan Covid-19 di Indonesia. Amnesti: Jurnal Hukum, 3(1), 37-52. http://jurnal.umpwr.ac.id/index.php/amnesti/article/view /929/703.

Rangaswamy, A., Moch, N., Felten, C., van Bruggen, G., Wieringa, J. E., \& Wirtz, J. (2020). The Role of Marketing in Digital Business Platforms. Journal of Interactive Marketing, 51(xxxx), 72-90. https://doi.org/10.1016/j.intmar.2020.04.006.

Riduwan, A. (2016). Pelaksanaan Kegiatan Pengabdian Kepada Masyarakat Oleh Perguruan Tinggi. Ekuitas (Jurnal Ekonomi Dan Keuangan), 3(1). https://doi.org/i:10.24034/j25485024.y1999.v3.i2.1886.

Rizal, F., \& Mukaromah, H. (2021). Filantropi Islam Solusi Atas Masalah Kemiskinan Akibat Pandemi Covid-19. Jurnal Hukum Dan Pranata Sosial Islam, 3(1), 35-66. https://ejournal.insuriponorogo. ac.id/index.php/almanhaj/article/view/631/327.

Sari, Y. I. (2020). Sisi Terang Pandemi Covid-19. Jurnal Ilmiah Hubungan Internasiona, 1(1). https://doi.org/https://doi.org/10.26593/jihi.v0i0.3878.89-94.

Suci, Y. R. (2013). Perkembangan UMKM (Usaha Mikro Kecil Dan Menengah) Di Indonesia. Jurnal Ilmiah Cano Ekonomos, 6(1). https://journal.upp.ac.id/index.php/cano/article/view/627.

Tarigan, R. (2020). Kuliah Kerja Mahasiswa (KKM) di Masa Pandemi Covid-19 Sebagai Salah Satu Bentuk Pengabdian Kepada Masyarakat. Jurnal ABDIKARYA, 2(2), 142157. http://www.riset.unisma.ac.id/index.php/JP2M/article/view/8776/7625.

Thaha, A. F. (2020). Dampak Covid-19 Terhadap UMKM Di Indonesia. Jurnal Brand, 2(1). http://ejournals.umma.ac.id/index.php/brand/article/view/607/445.

Verhoef, P. C., \& Bijmolt, T. H. A. (2019). Marketing perspectives on digital business models: A framework and overview of the special issue. International Journal of Research in Marketing, 36(3), 341-349. https://doi.org/10.1016/j.ijresmar.2019.08.001.

Yamali, F. R., \& Putri, R. N. (2020). Dampak Covid-19 Terhadap Ekonomi Indonesia. Journal of Economics and Business, 4(2), 384-388. https://doi.org/10.33087/ekonomis.v4i2.179.

Yunus, N. R., \& Rezki, A. (2020). Kebijakan Pemberlakuan Lock Down Sebagai Antisipasi Penyebaran Corona Virus Covid-19. SALAM: Jurnal Sosial Dan Budaya Syar-I, 7(3). https://doi.org/10.15408/sjsbs.v7i3.15083. 